\title{
A New Interpretation of the Mongolian Inscription on "Wan shou baita" in Aohan Banner
}

\section{Zheng Yue}

Inner Mongolia University, School of Mongolian Studies, Hohhot 010021

Keywords: "Wanshou baita"; inscription in Mongolian language; interpretation; academic value

\begin{abstract}
This article reinterprets two Mongolian inscriptions on Aohan Banner "Wan shou baita", complements the Chinese translation on the basis of the Latin transliteration, and expounds the inscriptions on the characteristics of Mongolian language philology and the significance of historical religions.
\end{abstract}

\section{Introduction}

Aohan Banner is located in the southeast of Chifeng City, Inner Mongolia Autonomous Region. It has a long history, one after another for the East Hu, Xianbei, Khitan, the Jin Dynasty, Yuan, Ming and Qing dynasties into the Mongols. North Yuan Dynasty under the Chahar Wanhu. There are Genghis Khan's XIX generation descendant Daiqingdureng with his brother Esenweizheng (Mongolia Naiman Department of the trip) led his family out of nomadic Chahaer in Laoha River, the number of the Ministry Aohan said. Aohan was compiled in 1636 as a Ruling county(Zha Sa ke county), belonging to Zhao Wuda League.

\section{2. "Wanshou baita" and its inscriptions}

The "Wanshou baita" (Figure 1) is located within the city site of the west of the 50th sub-village of Manihan Township, Aohan Banner. From the city site unearthed other inscriptions literature, it is the Yuan Dynasty Ningchang Road ruins of the ancient city [1]. The cultural characteristics represented by "Wanshou baita" belong to the Mongolian Aohan tribes, which reflect the Mongolian Aohan tribes at the time of their social, historical, Buddhist and even linguistic forms.

The inscription on the tower of "Wanshou baita" was engraved in the late Yuan and early Ming dynasties. Its historical, philological and linguistic values aroused academic attention. It is one of the important parts of Mongolian studies.

Tower under the front of a niche inlaid with a rectangular inscription, about $85 \mathrm{~cm}$ long and $37 \mathrm{~cm}$ wide. There are 27 lines of Mongolian engraved on the top, followed by the Mongolian 1 line of Chinese characters (Figure 2). The third eaves above the tower are inlaid with inscriptions of $170 \mathrm{~cm}$ in length and 25cm in width, engraved with 35 lines of Mongolian and 7 lines of Chinese (Figure 3). The inscription on the front of the tower is called "Wanli Thirty-one Year Inscription" and the inscription at the third tower eaves is called "The inscription of Wanli twenty-eight years." The two inscriptions began with the study of Chinese inscriptions in the 1980s. In 1989, Mr. Shaw Kuo-tian, Aohan Banner Museum, Chifeng, discovered the inscription of "Wanli twenty-eight years" for the earliest, and explained the Chinese part of it [2]. Two Baoyin professors from Inner Mongolia University published two monographs. In this paper, the two Chinese inscriptions of Mongolian and Mongolian inscriptions are respectively interpreted and compared, and the gains and losses of the previous research results are commented. According to the study of two BaoYin professors, "Wanli Twenty-eight inscriptions" Chinese as: "Ming qi chen Han, Wanshou baita, Ming Dynasty Wanli boxer twenty-eight years in autumn August, Daicheng bingdu-yunduqi, Dalahan baduer-dulingjia, Da-Yuan Huang Taiji life insurance" [3] (the original tablet for the vertical form of writing, Chinese reading order have different views); "Wanli thirty-one year inscription" Chinese as "Wanli Sanshiyi-nian sui-ci ji-dan-ri ".

The two inscriptions on Mongolian studies began with the above papers by two BaoYin 
professors. Papers (on) "Wanli twenty-eight inscriptions" Mongolian words to the Latin transliteration of the proper nouns and some words to do the history and meaning of word explanation. Most of the words they reconstructed after 18 lines were inconsistent with the actual written form. They read through the Mongolian inscriptions on the basis of re-examine and compare the correct order of Chinese, basically solved the differences in the interpretation of Chinese. Papers (Part Two) [4] on the "Wanli thirty-one year inscription," the Mongolian words transliteration and interpretation of words, the inscription of Mongolian inscriptions on the historical value of the paper to be summed up and affirmed. Changhai researchers titled "Translation and Interpretation of Mongolian Inscriptions in Wanshou baita and Thirty-one Years in Mongolian History of Wanli" [5], and first translated and interpreted Mongolian texts by two professors BaoYin. Among them, some historical figures and Buddhist terms are explained in more detail, but the interpretation of some words is debatable. This article illustrates the importance of this inscription in the history of Mongolia and the history of Buddhism in the Ming Dynasty. In this article, I re-interpret the two Mongolian inscriptions, which can make up for and improve the deficiencies and shortcomings in the above studies.

"Wanli twenty-eight inscriptions" Translated by Mongolian Latin *

Oom so(owa)sdi /Sidem./Tengsel ügei/Gurban čaG_un/Burqan_i teyn/Sečen qaGan_u čaG_/tu dayčing bing_/tu ildüči darqan/Dügüreng tayǰi /Amin nasun_a tula_L_da nay1man talatu /Arban Gurban al__ta suburGan qulu_/Guna jul_ün dolu_/Gan sarayin arban/Nigen edür busGla_/_ba.dgelüng dar_/_qan ečige lam_a/jiruGači lam_a /biči_/_geči lam_a nom šaji_/ni delgebe.Tümen_/nasutu čaGan subu_/rGan tayji /üyǰeng darqan ban_/_di küčiyen ögči

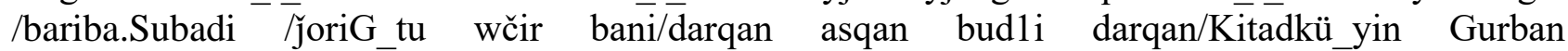
kümün/SuburGan_du demneju küčiyen /ögbe.Yeke engke amuGulang/Neretünasutu buy.Yeke/Ulus engke amuGulang /Nasu qutuG bolqu/BoltuGay.

Chinese translation: Yuan jixiang ankang / jiezhu wuliang sanshi fo / Naban Qi-chen-han zhishi/ Dai-Qing-bingdu-yunduqi, Dalahan-dureng- taiji / Wei yannian yishou(life insurance), Yu geng-zi-nian qiyue shiyiri (jian) li le bamian shisanzhang ta. / Gelung dalahan eqige lama, huajiang lama chuanbo fojing fojiao le. / Wanshou baita by Taiji wei-zheng Dalahan ban-di chuli jianzao. / Subadi-zhaorigetu-jingangchi, Dalahan-ashihan-bidi,Dlahan-qitateku deng sanren xiangzhu chuli le./You kangxi ming de wansui//Weida tianxia ankang/yannian.

"Wanli Thirty-one year inscription" Translated by Mongolian Latin

Oom so(owa)sdi sidem nasu/QutuG nemekü boltuGay.QutuG_tu/QaGan_u tustu. Darqan nangsu lam_a|Dügüreng dayčing tayǰi qoyar učara_/lduba.Uridu töröl_tü qoyar/ČiGulGan_i saytur quriyaGsan qotu_/la tegüsügsen sayn duradquy_tu_yin/Küčün_i čcočolaGsan buGda wčir baniyin $\backslash$ QubilGan dügüreng dayčing tayǰi/ba dalay bodisug qatun inü sayn $\backslash$ Anda bodisug Sunam Sereng qoyar\Tayǰi Dorǰi isgeb čaGan dara/Badma Radna dörben abaGai./Daiduyin qaGan_ača dörben subarGači kümün_i ab___čirajuu tümen ulus_un küčüber Radna delger /Ubaši saramiri ubaši qoyar_iyar Gurban/jaGun kümün_i jakirGaju amitan_u tusa /Bütügeküy_in tula nayman talatu altan /SubarGan bayGulbay. Ede/jaysang-uud metü nökör següder bügüdeger küčü/_ben öggülčebey širGalčuG kitad dayduy/_in $\square$ šitu batu muǰang teǰing šiǰang $\square /$ Vung sevu waǰang tusalalčabay./QamuG amitan_u ebedčin ada\TudarG1 anu arilju engke amu__Gulang jirGaqu boltuGay./ölǰey qutuG orušiqu boltuGay.

Chinese translation: Yuan jixiang ankang! / Qiyuan yannian yishou! / Wei Hu-dun-tu kehan. / Dalahan-nangsu-lama he Duling-daiqing-taiji erren xiangyu le. /Shanji qianshi liangjie yuan xiude puhui shanty zhili de Shengjingangshou zhuanshi-Duling-daiqing-taiji yu Dalai-putisatuo qi,liangyou Putisatuo-suonuomu yu Seleng liang taiji,Daoerjizhabu,Chahandala,Badama,Latena siwei gongzhu./Cong Dadu kehan chu qinglai siwei jiantashi,yi wanren zhili,ling latena-deligeer-wubaxi he Salamili-wubaxi erren zhihui sanbairen,wei liyi zhongsheng jianzao le bamian jinta./Zhexie zaisang deng suicong renyuan dou chuli le.Xirihachuke,qitate,Dadu de Shitou,Batu-mujiang, tiejiang shijiang deng Fengshifu,Wajiang xiangzhu le./Yuan zhongsheng zhi bingmo he jiku xiaoshi, xingfuankang!jixiang yongzhu! 


\section{3."Wanshou baita" inscription Mongolian language and linguistics characteristics}

From the two inscriptions of the Mongolian and Chinese records, they belong to the era of the North yuan. From the Mongolian writing features and Orthography and the Mongolian situation, it belongs to the middle stage of Mongolian written language, which fully reflects the characteristics of Mongolian transition from early transition to modern times.

(1) Both inscriptions still retain some of the characteristics of medieval Mongolian. Such as: n, G no "point"; in the word č, j form no significant difference; The first word q, G different; punctuation usage and so on. (2) Some of the early Mongolian landmark disappeared, such as: the vertical form of the end of the word a, e; ellipsis of the word yod; inconsistencies in the formulation of additional components of the structure and the formation of the word, all of which are transitional features. (3) Mongolian Ali Gali basically belongs to the embryonic stage. (4) Occurrence rate the named in the names of persons in Sanskrit and Tibetan language words is higher. use of some Buddhist terms indicate the increasing number of Buddhism elements in Mongolian language and the borrowing of Chinese borrowings in the name of occupation.

The overall appearance of the inscription shows that the Mongolian language in the Northern Yuan Dynasty has become a relatively mature phonetic script. As the official language of the Mongolian society, it maintains a certain degree of vitality within a specific environment and scope (the period of the Northern Yuan Dynasty). In short, the two Mongolian inscriptions make up for the lack of literature on Mongolian inscriptions during this period, filling up the Mongolian document thesaurus with more vocabularies, thus enriching Mongolian information from the end of the 16th century to the beginning of the 17th century, providing more basis for the history of Mongolian language development.

\section{4. "Wanshou baita" inscription Mongolian history, religious significance}

"Wanli twenty-eight inscriptions" and "Wanli thirty-one inscriptions" were formed in 1600 (Geng $\mathrm{Zi}$ ) and 1603 years. Inscriptions recorded in Mongolian records of the Northern Yuan Dynasty Genghis Khan descendants of borjigin gold family important historical figures and their building tower deeds and related information.

(1) Historical figures are: Qi Shen Han and Buyanchechen-han: successor to 1593, died in 1603, the account in Chahar Wanhu; Huduntuhan-kehan(Lindanhan) : 1603 succession Mongolia Khan bit, Buyanchechen-han grandson; Dai Qing-bingdu-yunduqi: Nobility of Alakechude tribe; Duleng-daiqing: Nobility of Aohan tribe ; Bandi: First leader of Aohan banner;Supabid: First leader of Outer Mongolian; Budi: First leader of the iner Mongolian Keerqin-youyi-qianqi banner ; Qitateku : Nobility of Haoqite tribe of Chahaer Wanhu; Dalai-Putisatuo-lama: Duling-daiqing's wife; Suonuomu and and Seleng: Duling- daiqing's Two sons;

(2) "Wanli Twenty-eight Years Inscription" About Lindan-han's records are different from other historical documents, many of the records of Mongolian history Lindan-han in 1604, but the inscription was recorded as 1603 years. Daiqing-duling wife and his son's name was first recorded in history;

(3) In the inscription, it can be learned that the tribes of Mongolia, especially the Chahar tribes, supported the proclamation of Buyanchechen-han and Lindan-han and the regime of the North Yuan remained lament to the death of Lindanhan (1634).

(4) The inscription appeared in the history of Mongolian Buddhism important figure. Gelung -dalahan-eqige-lama: also known as A Xing Lama, Gelu Sect, the third Dalai Lama's uncle, began in Mongolia's right-wing missionary, after the Jin Dynasty Emperor invited to Shengjing, and later became Siletukulun The first leader ; Dalahan-nangsu-lama: the brother of Axing-lama, and the second leader of Xiletukulun Banner, who preached in the left-Banner of Mongolia such as Horqin.

In short, the two inscriptions record years of the mouse and Wanli thirty-one years, the Aohan tribes led Chahar Wanhu left and other neighboring tribes of aristocrats to Buyanchechen-han, Lindan-han and beings pray for well-being Longevity, building tower missionary deeds. The two inscriptions further clarify the links between the Horde of Etuoke (camp) and the Mongolian tribes 
in Chahar left-Banner tribes in Mongolia in the 16th-17th century. The Chahar Wanhu and the Gelug Sects of Tibetan Buddhism, the Ming and Qing dynasties History of the relationship between Mongolia Aohan tribal histories provides a valuable historical data. Together with the "Wanshou Baita" itself and other unearthed relics, the two inscriptions are an indispensable evidence of the history of Buddhism in Mongolia and Aohan Banner.

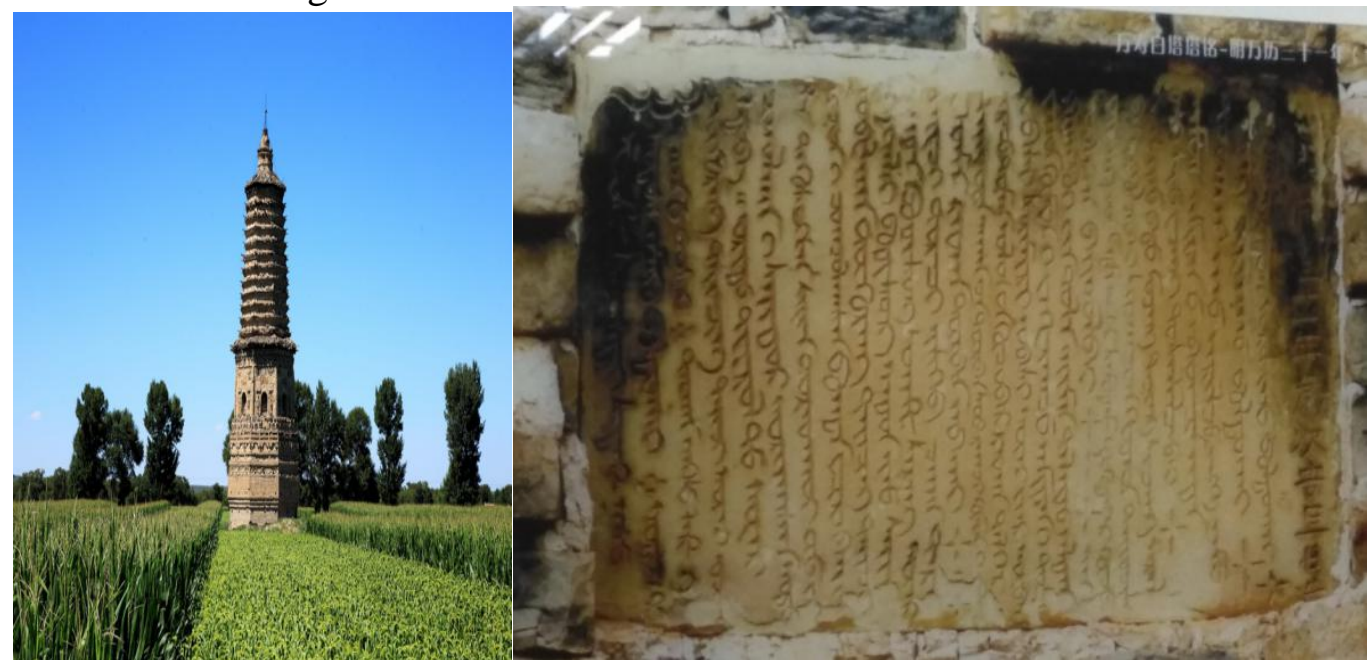

Figure 1: Aohan flag "Wanshou baita" Figure 2: "Wanli thirty-one inscriptions"

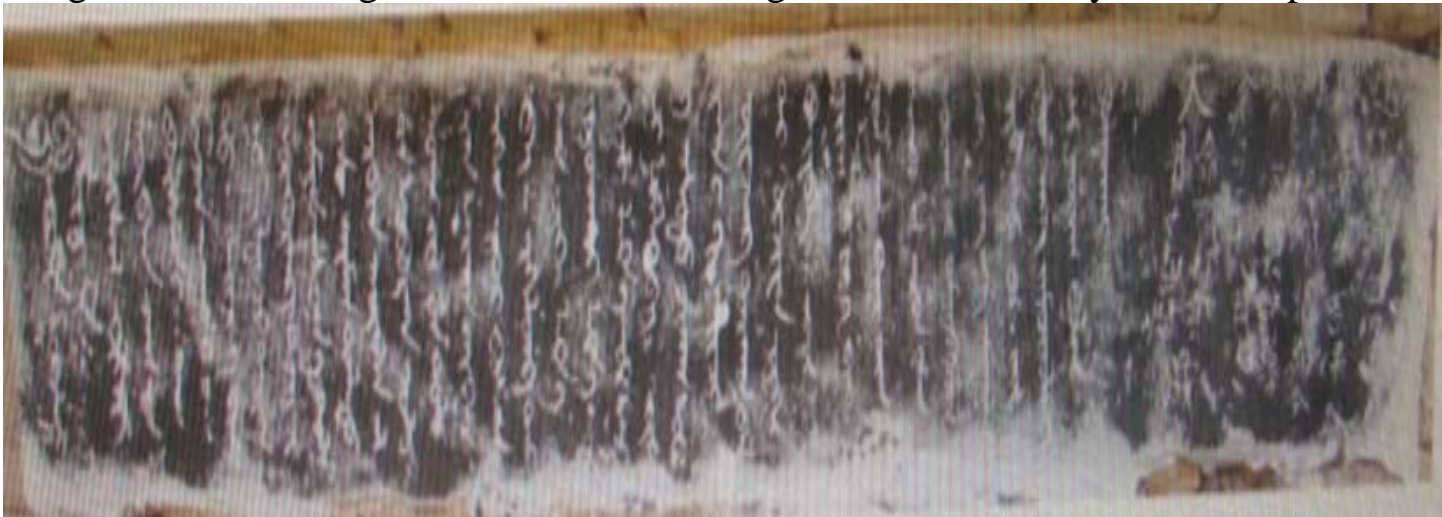

Figure 3: "Wanli twenty-eight inscriptions"

\section{References}

[1] Inner Mongolia Autonomous Region Institute of Cultural Relics and Archeology editor: "Chifeng Cultural Heritage", Heritage Publishing House, 2014, p. 203.

[2] "Yuan Ningchang Buddhist pagoda found inscriptions", "Chifeng Daily", December 23, 1989.

[3] “The Mongolian historical dictionary”, by Buoyinhu, Inner Mongolia university press,2010.

[4][5] "Aohanqi territory" Wanshou Baita "Mongolian and Chinese stone research" (on) "Journal of Inner Mongolia University" (Mongolian), 2015 fourth period, the first 81 pages. 